Article

\title{
Corn Forage Yield and Quality for Silage in Short Growing Season Areas of the Canadian Prairies
}

\author{
Jessie Guyader ${ }^{1}$, Vern S. Baron ${ }^{2}$ and Karen A. Beauchemin ${ }^{1, * \text { (D) }}$ \\ 1 Agriculture and Agri-Food Canada, Lethbridge Research and Development Centre, \\ Lethbridge, AB T1J 4B1, Canada; Jess.guyader@hotmail.fr \\ 2 Agriculture and Agri-Food Canada, Alberta Agriculture and Food at 6000 C \& E Trail, \\ Lacombe, AB T4L 1W1, Canada; vern.baron@agr.gc.ca \\ * Correspondence: Karen.beauchemin@agr.gc.ca; Tel.: +1-403-317-2235
}

Received: 2 August 2018; Accepted: 23 August 2018; Published: 27 August 2018

\begin{abstract}
The development of short-season hybrids has made corn (Zea mays L.) silage (CS) production possible in cooler areas. This work aimed at determining biomass yield and nutritive quality of short-season corn CS hybrids. Six corn hybrids were grown in three years at four locations within the Canadian prairies with four field replications. Hybrids were harvested before occurrence of frost at a target dry matter (DM) content of 300 to $400 \mathrm{~g} \mathrm{~kg}^{-1}$. Corn heat units (CHU) from seeding to harvesting $\left(\mathrm{CHU}_{\text {seed-harv }}\right)$ and water supply were recorded. Samples were analysed for nutrient content; i.e., DM, neutral detergent fiber (NDF), crude protein $(\mathrm{CP})$, starch, and in vitro DM and NDF digestibilities (48 $\mathrm{h}$ incubation). Then, $\mathrm{CHU}_{\text {seed-harv }}$, water supply, whole plant $\mathrm{DM}, \mathrm{CHU}$ rating of the hybrid, and cob percentage were assessed as predictors of nutrient content. Location, hybrid, and year affected nutrient composition and yield. Overall, CP and NDF were positively correlated $(r=0.48, p<0.01)$, but both were negatively correlated with DM yield $(r=-0.63,-0.28, p<0.01)$ and starch (both $r=0.71, p<0.01$ ). Within and among locations, $\mathrm{CHU}_{\text {seed-harv }}$ differently affected nutrient composition and DM yield. However, DM yield was the most predictable factor $\left(R^{2}=0.86\right)$ with $\mathrm{CHU}_{\text {seed-harv }}$ being the strongest contributor $(48 \%)$ to the overall variability, followed by water supply $(23 \%)$. Whole plant DM and $\mathrm{CHU}_{\text {seed-harv }}$ were also good predictors of starch $\left(R^{2}=0.54\right)$. This work showed the high variability of biomass yield and nutritive quality of short-season CS hybrids grown in Northern areas.
\end{abstract}

Keywords: corn silage; hybrids; maize; in vitro digestibility; yield; short growing season

\section{Introduction}

Availability of short-season corn hybrids has made corn silage (CS) production possible in areas with shorter growing season [1,2]. Consequently, CS production in Canada increased by $28 \%$ between 2011 and 2016 (from 273,178 ha to 383,879 ha), with the greatest increase in the Canadian prairies (+35\% in Manitoba (MB),$+73 \%$ in Saskatchewan, and $+52 \%$ in Alberta (AB); [3]). Expansion of CS production is also due to its potential for high yield and digestibility and greater lodging resistance compared to small grains such as barley and oats [4]. Given that beef and dairy cattle production are limited by digestible energy intake [5], CS represents an opportunity to increase meat and milk production without expanding land usage.

However, corn grown on the Canadian prairies for silage does not always achieve its potential due to a cool environment where season-length and temperature limit kernel filling, maturation, and attainment of the required 320-380 $\mathrm{g} \mathrm{kg}^{-1}$ whole plant DM content necessary for ensiling. Daynard [6] reviewed the dynamics of whole plant DM concentration for corn, the achievement of maximum silage and grain yield during the grain filling period, and the consequences this has on ensiling and nutritive 
value of corn silage in short-season regions in Canada. Corn hybrids may not attain $300 \mathrm{~g} \mathrm{~kg}^{-1} \mathrm{DM}$ prior to autumn frost, especially when their maturity rating in corn heat units (CHU; [7]) is greater than that of the adaptation zone. It was concluded [6] that attainment of $250 \mathrm{~g} \mathrm{~kg}^{-1} \mathrm{DM}$ might be acceptable for ensiling, although limitations to digestible intake by ruminants could occur. Since the study of Daynard [6], corn hybrids as early as 2000 CHU rating (Minnesota Relative Maturity (MRM) $=52$, using equation given by [8]) have become available compared to the earliest hybrids with $2300 \mathrm{CHU}$ $(\mathrm{MRM}=65)$ in the 1970s. The availability of early maturing hybrids has enlarged the area of corn adaptation in western Canada, but some of the same short-season issues [6] impact CS yield and cause variability in nutritive value. In warmer regions, yield of CS is maximized at greater DM concentrations, and consequently grain content is increased, but this is not always possible in short-season growing areas because of early occurrence of frost.

Previous research found little change in in vitro digestibility of the whole plant post-silking through the grain filling period [9]. Inversely, whereas starch concentration increased in adapted Wisconsin CS from $182 \mathrm{~g} \mathrm{~kg}^{-1}$ at $300 \mathrm{~g} \mathrm{~kg}^{-1}$ whole plant DM to $370 \mathrm{~g} \mathrm{~kg}^{-1}$ at $350 \mathrm{~g} \mathrm{~kg}^{-1} \mathrm{DM}$, with starch digestibility exceeding $90 \%$, fiber digestibility decreased over this period [10]. Current information on changes in fiber digestibility and starch accumulation and digestibility during the grain filling period indicates these off-setting factors impact animal performance $[5,10]$. However, there is a lack of information concerning these parameters and relationships with corn hybrid maturity when grown among and within short-season CHU zones in western Canada.

Economic production of CS is dependent on silage DM yield and nutritive value. Given that yield is positively correlated with $\mathrm{CHU}$ accumulation and hybrid maturity [6] and nutritive value is affected by maturity, a better understanding among these parameters and with $\mathrm{CHU}$ accumulation across $\mathrm{CHU}$ zones in short-season growing areas in Canada is required. Therefore, the first objective of this work was to determine the DM yield and nutrient content (chemical composition, in vitro digestibility) of short-season CS hybrids having a wide range in CHU rating to maturity (2000 to 2600) and grown in various $\mathrm{CHU}$ zones. The second objective was to develop relationships between silage DM yield and nutrient content with accumulated $\mathrm{CHU}$ and other environmental factors.

\section{Materials and Methods}

\subsection{Experimental Design and Agronomic Practices}

Corn was grown for three years $(2013,2014$, and 2015) in four different locations (Lacombe, AB; Lethbridge, $\mathrm{AB}$; Vauxhall, $\mathrm{AB}$; Elm Creek, $\mathrm{MB}$ ) representing the range in environmental conditions of CS-producing areas within the Canadian prairies (Table 1). 
Table 1. Location, soil description and long-term climatic information for Lacombe, Lethbridge, and Vauxhall (Alberta) and Elm Creek (Manitoba).

\begin{tabular}{|c|c|c|c|c|}
\hline \multirow[b]{2}{*}{ Parameter } & \multicolumn{4}{|c|}{ Location } \\
\hline & Lacombe & Lethbridge & Vauxhall & Elm Creek \\
\hline Latitude & $52^{\circ} 28^{\prime} \mathrm{N}$ & $49^{\circ} 37^{\prime} \mathrm{N}$ & $50^{\circ} 11^{\prime} \mathrm{N}$ & $49^{\circ} 40^{\prime} \mathrm{N}$ \\
\hline Longitude & $113^{\circ} 45^{\prime} \mathrm{W}$ & $112^{\circ} 48^{\prime} \mathrm{W}$ & $112^{\circ} 07^{\prime} \mathrm{W}$ & $97^{\circ} 59^{\prime} \mathrm{W}$ \\
\hline \multirow[t]{2}{*}{ Elevation, $\mathrm{m}$} & 850 & 929 & 760 & 239 \\
\hline & \multicolumn{4}{|c|}{ Soil Description +} \\
\hline Texture & Fine sandy loam & Silt loam & Silt loam & Sandy loam \\
\hline \multirow[t]{2}{*}{ Classification } & $\begin{array}{l}\text { Orthic black chernozem } \\
\text { (Udic Borroll) }\end{array}$ & $\begin{array}{l}\text { Orthic dark brown chernozem } \\
\text { (Typic Borroll) }\end{array}$ & $\begin{array}{c}\text { Orthic brown chernozem } \\
\text { (Aridic Boroll) }\end{array}$ & $\begin{array}{l}\text { Gleyed black chernozem } \\
\text { (Udic Borroll) }\end{array}$ \\
\hline & \multicolumn{4}{|c|}{ Climatic Normal $\ddagger$} \\
\hline Mean temperature, ${ }^{\circ} \mathrm{C}$ & 12.2 & 13.6 & 13.3 & 13.9 \\
\hline Accumulated precipitation, $\mathrm{mm}$ & 376.6 & 273.3 & 228.0 & 416.4 \\
\hline Accumulated $\mathrm{CHU}_{\text {seed-harv }} \S$ & 1955 & 2448 & 2538 & 2463 \\
\hline Growing season CHUI & 2025 & 2135 & 2161 & 2590 \\
\hline Average date of first autumn frost & 11 September & 17 September & 23 September & 22 September \\
\hline
\end{tabular}

† Michalyna et al. [11]; Canadian Soil Information System [12]. Definition of soil texture can be obtained from Soil Classification Working Group [13]. ‡ Average data between May and Oct. from 1981 to 2010; Government of Canada [14]. § Corn heat units determined from planting date until harvest date (not until first autumn frost). II Average corn heat units during the growing season from 1976 to 2005 [15. 
At each location, six short/medium season CS hybrids were planted $\left(74,000\right.$ seeds ha ${ }^{-1}$; row spacing $75 \mathrm{~cm} ; 11.0 \mathrm{~m}^{2}$ average plot size) in four replicates in a randomized complete block design each year. Given that each location has a different long-term CHU rating, hybrids were selected to be adapted within each zone with some overlap (Table 2). While some overlap for hybrids existed among locations it was not possible to satisfy sufficient adaptation among hybrids and use identical hybrids in all locations. Given the lack of short-season hybrids for the Lacombe location, earliest maturing hybrids available were used. This difference in hybrids among locations was considered in the statistical analyses and interpretation.

Table 2. Selected corn hybrids with grain maturity ratings for Lacombe, Lethbridge, and Vauxhall (Alberta) and Elm Creek (Manitoba) over three years.

\begin{tabular}{|c|c|c|c|}
\hline Hybrid t & CHU rating & Hybrid $t$ & CHU rating \\
\hline \multicolumn{2}{|c|}{ Lacombe } & \multicolumn{2}{|c|}{ Vauxhall } \\
\hline P39F44 & 2000 & P7632HR & 2200 \\
\hline P7213R & 2050 & 39V05 & 2250 \\
\hline P39M26 & 2100 & P8193AM & 2400 \\
\hline Edge & 2150 & P8210HRI & 2475 \\
\hline 2262RR & 2175 & P8673AM & 2550 \\
\hline P7632HR & 2200 & P8622AM & 2600 \\
\hline \multicolumn{2}{|c|}{ Lethbridge } & \multicolumn{2}{|c|}{ Elm Creek } \\
\hline P39F44 & 2000 & 39D95 & 2175 \\
\hline P7443R & 2100 & P7632HR & 2200 \\
\hline P7632HR & 2200 & 39V05 & 2250 \\
\hline 39V05 & 2250 & P8016AM § & 2350 \\
\hline P8673AM & 2550 & P8673AM & 2550 \\
\hline P8210HR $\ddagger$ & 2600 & P8906AM & 2650 \\
\hline
\end{tabular}

† Hybrids were supplied by Pioneer Hi-Bred, Johnston (IA) except for hybrids Edge (Elite, Saint-Hyacinthe, QC, Canada) and 2262RR (Pickseed, Lindsay, ON, Canada). $\ddagger$ Hybrid P8210HR was replaced by P8622AM in year 1. II Hybrid P8210HR was replaced by P8016AM in year 2. § Hybrid P8016AM was replaced by P8210HR in year 3.

In all locations and years, corn was seeded prior to May 20 except for Elm Creek in 2014 and 2015, and harvest occurred in September except for Elm Creek in 2014 (Table 3). The decision was made to harvest just before occurrence of frost, rather than at a prescribed DM concentration as it was expected that not all hybrids would attain $300 \mathrm{~g} \mathrm{~kg}^{-1} \mathrm{DM}$ prior to frost. Corn was planted with a three-point hitch two-row corn planter at Lacombe, Lethbridge, and Vauxhall (John Deere, Moline, IL, US) and Elm Creek (Plot King 2600, Wintersteiger AG, Innkreis, Austria). A two-row corn silage harvester was used at Lacombe, Lethbridge, and Vauxhall (John Deere Model 3940 in Lacombe and Model 8320 in Lethbridge and Vauxhall). A single-row harvester was used at Elm Creek (Model 717, New Holland, Turin, Italy). 
Table 3. Seeding date, the first and the last mean silking date, and harvesting date for corn hybrids grown at Lacombe, Lethbridge, and Vauxhall (Alberta) and Elm Creek (Manitoba) over three years.

\begin{tabular}{cccc}
\hline Year & Seeding Date & First and Last Silking Datet & Harvesting Date \\
\hline \multicolumn{4}{c}{ Lacombe } \\
\hline 2013 & 10 May & 3 August-19 August & 18 September \\
2014 & 16 May & 31 July-9 August & 16 September \\
2015 & 5 May & 23 July-3 August & 15 September \\
& \multicolumn{4}{c}{ Lethbridge } \\
\hline 2013 & 8 May & 23 July-10 August & 22 September \\
2014 & 22 May & 8 August-13 August & 22 September \\
2015 & 6 May & 15 July-31 July & 18 September \\
& & Vauxhall & 24 September \\
\hline 2013 & 17 May & 3 August-12 August & 21 September \\
2014 & 29 May & 8 August-13 August & 18 September \\
2015 & 3 June & 18 July-30 July & Elm Creek \\
& & 29 July-2 August & 17 September \\
2013 & 13 May & 5 August-11 August & 8 October \\
2014 & 19 May & 29 July-6 August & 24 September \\
\hline
\end{tabular}

t Mean silking date of earliest and latest hybrid at the location.

Minimum, maximum, and mean daily temperatures between seeding and harvesting, as well as precipitation were recorded based on the on-site or closest $(<25 \mathrm{~km})$ weather station. The CHU accumulated between seeding and harvesting $\left(\mathrm{CHU}_{\text {seed-harv }}\right)$, and between silking and harvesting $\left(\mathrm{CHU}_{\text {silk-harv }}\right)$, were calculated for each year and location as the sum of daily $\mathrm{CHU}$ provided by Government of Canada [14] between the targeted periods. Initiation for summation of CHU at each location and year used the method outlined by Huggins-Rawlins [16]. The final day of CHU accumulation at each location and year corresponded to the silage harvesting date. Water supply and mineral fertilization per location and year are presented in Table 4. Fields were only irrigated in Lethbridge and Vauxhall. Crops were fertilized to excess, so that only maturity and climate were the limiting factors for CS development. 
Table 4. Environmental data, accumulated corn heat unit (CHU), and inorganic fertilization rate at Lacombe, Lethbridge, and Vauxhall (Alberta) and Elm Creek (Manitoba) over three years.

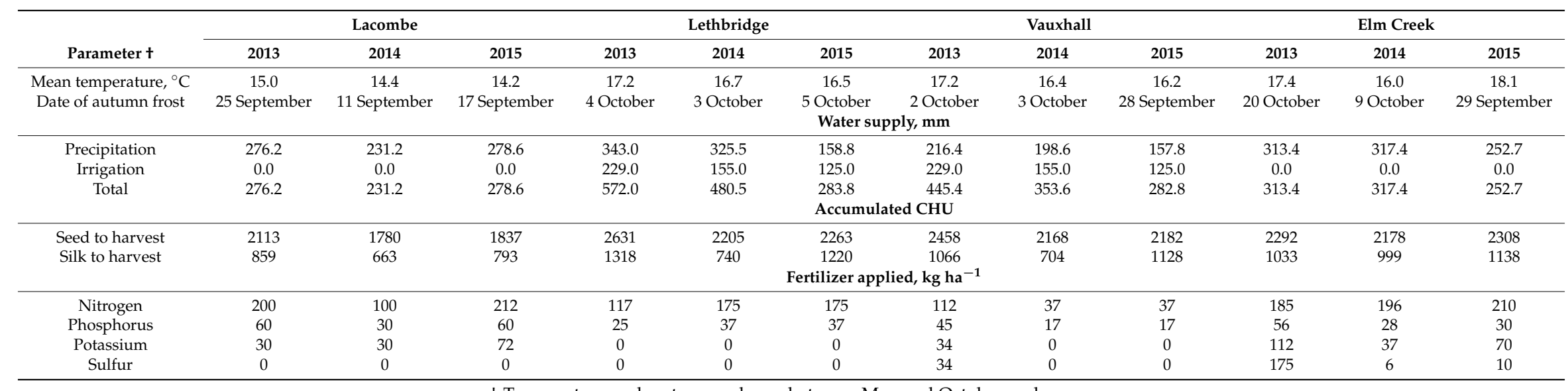

+ Temperature and water supply are between May and October each year. 


\subsection{Sampling and Chemical Analysis}

Upon harvesting, five plants per replicate were separated into ear and stover, and weighed. The remaining plants were harvested, weighed to determine total wet weight biomass (weight of five plants was included) and a 5-kg representative sample was retained to determine DM concentration and nutritive quality. Samples were frozen and shipped to the Lethbridge Research and Development Centre (LeRDC, Agriculture and Agri-Food, Lethbridge, AB, Canada) where they were dried to a constant weight at $55^{\circ} \mathrm{C}$ prior to further processing.

Dried samples were ground in a Wiley mill (A.H. Thomas, Philadelphia, PA, USA) through a 4-mm screen. A subsample was further ground through a 1-mm screen and another subsample was ball-ground (mixer mill MM 400; Retsch Inc., Newtown, PA). All samples from year 1 year were analyzed in duplicate for DM $\left(135^{\circ} \mathrm{C}\right.$ for 2 hours; method 930.15; [17]), organic matter (OM; $550{ }^{\circ} \mathrm{C}$ for 5 hours; method 942.05; [17]), neutral detergent fiber (NDF), acid detergent fiber (ADF), acid detergent lignin (ADL), crude protein $(\mathrm{CP})$, and starch concentrations, as well as in vitro digestibility. Fiber (NDF and ADF) was determined by a sequential procedure [18] with the ANKOM200 Fiber Analyzer (Ankom Technology Corp, Macedon, NY, USA) after pre-treatment with sodium sulfite and $\alpha$-amylase and expressed inclusive of residual ash. Lignin was analyzed using ADF residues with the direct sulphuric acid (72\%) method [19]. The ball-ground samples were used to determine $\mathrm{CP}$ and starch concentrations. Starch was measured with an enzymatic method as described by Koenig et al. [20]. Nitrogen was analyzed by a combustion method with gas chromatography and thermal conductivity detection (Carlo Erba Instrumentals, Milan, Italy; method 990.03; [17]), and $\mathrm{CP}$ was calculated as $\mathrm{N} \times 6.25$. Dry matter digestibility (DMD) and NDF digestibility (NDFD) were determined after in vitro incubation for $48 \mathrm{~h}$ in a DAISYII Incubator (Ankom Technology, Macedon, NY, USA).

All samples that had been chemically analyzed were scanned using Near Infrared Reflectance spectroscopy (NIRSystems 6500 Monochromator, Foss NIRSystems Inc., Silver Spring, MD, USA). Prediction equations were developed, and the $R^{2}$ and $R^{2}$ of cross validation $\left(R^{2} \mathrm{CV}\right)$ were calculated. These were greater than 0.83 for DM, OM, ADF, ADL, starch, and CP. Because of lower values for $\operatorname{NDF}\left(R^{2} \mathrm{CV}=0.75, n=232\right), \operatorname{NDFD}\left(R^{2} \mathrm{CV}=0.42, n=235\right)$, and $\mathrm{DMD}\left(R^{2} \mathrm{CV}=0.46, n=230\right)$, the samples from year 2 and 3 were analyzed using the chemical and in vitro methods described for year 1 . The remaining nutrients (DM, OM, ADF, ADL, ADL, starch, and $\mathrm{CP}$ ) for samples from year 2 and 3 were predicted from the equations generated from year 1 samples.

\subsection{Statistical Analyses}

Statistical analyses were carried out with R software (Version 3.4.0; [21]). For a better understanding of the overall database, a principal component analysis was conducted (function "dudi.pca" of the package ade4), and graphical representation of variables ( $n=16$; component plots) was obtained with the "plot" and "s.class" functions. Then, for each location, the fixed effects of year, hybrid, and their interaction on specific parameters (nutrients, DM yield, and cob percentage) were tested with a linear model (function "lme" of the package nlme) using replicates as random effect. The "lsmeans" function (package lsmeans) was further applied on each model to calculate LSmeans and to conduct a pairwise comparison with a Bonferroni adjustment when hybrid or year effect was significant. Because of lack of seed availability, two hybrids had to be replaced by comparable hybrids in some years. Therefore, the LSmeans for the hybrids that were not grown in all three years within location are not presented in the tables, although they were used in the overall analysis. Correlations among nutrients, yields, and CHU were determined overall and within locations with the "rcorr" function (package Hmisc). Overall prediction equations of nutrient composition based on indicators directly measurable in the field $\left(\mathrm{CHU}_{\text {seed-harv }}\right.$, total water supply, whole plant $\mathrm{DM}, \mathrm{CHU}$ rating, and cob percentage) were estimated with the "lm" function of the package relaimpo. Only indicators being significantly correlated with nutrients were included (except for total water supply). Relative importance of each predictor was 
calculated with the "calc.relimp" function. Data were considered significant at $p<0.05$, and tendencies were discussed at $0.05 \leq p \leq 0.10$.

\section{Results}

\subsection{Weather Compared to the Climatic Normals}

The accumulated $\mathrm{CHU}_{\text {seed-harv }}$ (Table 4) was above the long-term average climatic normals (Table 1) in all years for Lethbridge and Vauxhall, and in 2013 for Lacombe, but was below the climatic normal for Elm Creek in all years and Lacombe in 2014 and 2015. Averaged over the three years the accumulated $\mathrm{CHU}_{\text {seed-harv }}$ was $94 \%, 111 \%, 105 \%$, and $88 \%$ of the 1976-2005 year average for Lacombe, Lethbridge, Vauxhall, and Elm Creek, respectively. The date of first frost was much later than normal in eight of the nine location-years (Table 4). At Elm Creek, autumn frost ranged from almost a month later than average in 2013 to a week later in 2015. Although the actual frost date was later than the climatic normal at Elm Creek, the harvest date was close to expected frost date. While accumulated $\mathrm{CHU}$ was within the range expected for Lethbridge, the late harvest date (Table 4) due to the late occurrence of frost compared with the average date of autumn frost resulted in relatively mature corn (silage DM > $400 \mathrm{~g} \mathrm{~kg}^{-1}$ in 2013). Precipitation was below the climatic normal in all years at Lacombe and Elm Creek (Tables 1 and 4) and was augmented with irrigation at Lethbridge and Vauxhall.

\subsection{Location, Year, and Hybrid}

Although interactions $(p<0.05)$ between hybrid and year effects were rare in any location, hybrid and year effects were almost always significant $(p<0.05$; Tables $5-8)$. Parameters describing nutritive value were not reported for Lethbridge (Table 6) and Vauxhall (Table 7) in 2014 due to problems with sample drying. Thus, only yield, DM concentration and cob percentage were shown for these locations in 2014.

Only corn hybrid P39F44 matured adequately to meet the DM requirements for CS at Lacombe (Table 5). Indeed, excluding P39F44, no hybrid grown at Lacombe exceeded $300 \mathrm{~g} \mathrm{~kg}^{-1} \mathrm{DM}, 200 \mathrm{~g} \mathrm{~kg}^{-1}$ DM starch concentration, or 50\% cob percentage when averaged over years. Averaged over hybrids and years, the Lacombe location had relatively low DM content $\left(286 \mathrm{~g} \mathrm{~kg}^{-1}\right)$, DM yield $\left(9.5 \mathrm{Mg} \mathrm{ha}^{-1}\right)$, and starch concentration ( $\left.185 \mathrm{~g} \mathrm{~kg}^{-1} \mathrm{DM}\right)$. In two of three years, silage DM content averaged over hybrids did not reach $300 \mathrm{~g} \mathrm{~kg}^{-1}$. Corn DM yield in 2014 and 2015 was 56\% and $36 \%$ of the 2013 value, reflecting the earlier frost date and lower CHU accumulation in 2014 and reduced CHU accumulation and lack of precipitation prior to silking in 2015. The earliest maturing hybrid, P39F44 at $2000 \mathrm{CHU}$, achieved $>300 \mathrm{~g} \mathrm{~kg}^{-1} \mathrm{DM}$, highest starch concentration $\left(261 \mathrm{~g} \mathrm{~kg}^{-1} \mathrm{DM}\right)$ and cob percentage $(52.5 \%)$, and lowest ADL concentration $\left(20.8 \mathrm{~g} \mathrm{~kg}^{-1} \mathrm{DM}\right)$. However, averaged over years P3944 had the lowest average DM yield ( $80 \%$ of the other hybrids). Concentration of DMD did not differ among hybrids, but there was a tendency $(p=0.068)$ for hybrid differences in NDFD (ranging from 548 to $581 \mathrm{~g} \mathrm{~kg}^{-1} \mathrm{NDF}$ ). 
Table 5. Concentration of DM, starch, NDF, ADL, CP, DMD, NDFD, DM yield, and cob percentage for whole-plant corn grown at Lacombe (Alberta) over three years.

\begin{tabular}{|c|c|c|c|c|c|c|c|c|c|}
\hline & \multicolumn{7}{|c|}{ Nutrient $t$} & \multirow{2}{*}{ DM Yield } & \multirow{2}{*}{ Cob } \\
\hline & DM & Starch & NDF & ADL & $\mathbf{C P}$ & DMD & NDFD & & \\
\hline & & & & $\mathrm{kg}^{-1}$ & & & & $\mathrm{Mg} \mathrm{ha}^{-1}$ & $\% \mathrm{DM}$ \\
\hline \multicolumn{10}{|l|}{ Hybrid (H) } \\
\hline P39F44 & $304 \mathrm{a}$ & $261 \mathrm{a}$ & $533 a$ & $20.8 \mathrm{a}$ & 87.0 & 678 & 562 & $7.9 \mathrm{a}$ & $52.5 \mathrm{a}$ \\
\hline P7213R & $288 \mathrm{ab}$ & $177 \mathrm{bc}$ & $565 \mathrm{bc}$ & $25.0 \mathrm{~b}$ & 87.5 & 676 & 581 & $10.3 c$ & $48.5 \mathrm{~b}$ \\
\hline P39M26 & $288 \mathrm{ab}$ & $194 \mathrm{~b}$ & $541 \mathrm{ab}$ & $24.5 \mathrm{~b}$ & 84.8 & 669 & 548 & $10.0 \mathrm{bc}$ & $49.1 \mathrm{ab}$ \\
\hline Edge & $288 \mathrm{ab}$ & $163 c$ & $559 \mathrm{abc}$ & $25.2 \mathrm{~b}$ & 86.6 & 661 & 557 & $9.7 \mathrm{bc}$ & $45.3 \mathrm{bc}$ \\
\hline 2262RR & $283 \mathrm{bc}$ & $153 \mathrm{c}$ & 577 c & $25.2 \mathrm{~b}$ & 85.2 & 656 & 550 & $9.7 \mathrm{bc}$ & $41.6 \mathrm{c}$ \\
\hline P7632HR & $267 c$ & $148 \mathrm{c}$ & $580 \mathrm{c}$ & $25.9 \mathrm{~b}$ & 83.7 & 658 & 553 & $9.3 \mathrm{~b}$ & $42.9 \mathrm{c}$ \\
\hline \multicolumn{10}{|l|}{ Year (Y) } \\
\hline 2013 & $286 \mathrm{~b}$ & $189 \mathrm{ab}$ & $568 \mathrm{~b}$ & $21.6 \mathrm{a}$ & $82.5 \mathrm{a}$ & $681 \mathrm{~b}$ & $561 \mathrm{~b}$ & $14.8 \mathrm{c}$ & 47.0 \\
\hline 2014 & $328 \mathrm{c}$ & $163 \mathrm{a}$ & $581 \mathrm{~b}$ & $29.3 b$ & $93.2 \mathrm{~b}$ & $647 \mathrm{a}$ & 527 a & $8.3 \mathrm{~b}$ & 46.3 \\
\hline 2015 & $245 a$ & $200 \mathrm{~b}$ & 529 a & $22.4 \mathrm{a}$ & $81.7 \mathrm{a}$ & $671 \mathrm{~b}$ & $587 \mathrm{c}$ & $5.4 \mathrm{a}$ & 46.7 \\
\hline SEM & 8.1 & 12.0 & 11.8 & 0.12 & 1.94 & 12.4 & 14.2 & 0.42 & 1.59 \\
\hline$P$-Value $\mathrm{H} \ddagger$ & $<0.001$ & $<0.001$ & $<0.001$ & $<0.001$ & 0.16 & 0.14 & 0.068 & $<0.001$ & $<0.001$ \\
\hline$P$-Value $Y \ddagger$ & $<0.001$ & $<0.001$ & $<0.001$ & $<0.001$ & $<0.001$ & $<0.001$ & $<0.001$ & $<0.001$ & 0.67 \\
\hline$P$-Value $\mathrm{Y} \times \mathrm{H}$ & 0.056 & 0.064 & 0.47 & 0.277 & 0.21 & 0.86 & 0.34 & 0.28 & 0.25 \\
\hline
\end{tabular}

+ ADL, acid detergent lignin; CP, crude protein; DM, dry matter; DMD, 48 hours dry matter digestibility; NDF, neutral detergent fiber, all concentration of DM; NDFD, 48 hours neutral detergent fiber digestibility as concentration of NDF. $¥$ Within columns, means followed by the same letter $(a, b, c, d)$ are not significantly different among hybrids or years $(p<0.05)$. 
Table 6. Concentration of DM, starch, NDF, ADL, CP, DMD, NDFD, DM yield, and cob percentage for whole-plant corn grown at Lethbridge (Alberta) over three years.

\begin{tabular}{|c|c|c|c|c|c|c|c|c|c|}
\hline & \multicolumn{7}{|c|}{ Nutrient $t$} & \multirow{2}{*}{ DM Yield } & \multirow{2}{*}{ Cob } \\
\hline & DM & Starch & NDF & ADL & $\mathrm{CP}$ & DMD & NDFD & & \\
\hline & \multicolumn{7}{|c|}{$\mathrm{g} \mathrm{kg}^{-1}$} & $\mathrm{Mg} \mathrm{ha}^{-1}$ & $\% \mathrm{DM}$ \\
\hline \multicolumn{10}{|l|}{ Hybrid $(\mathrm{H})$} \\
\hline P39F44 & $453 \mathrm{a}$ & 325 & 527 & 20.8 & $75.8 \mathrm{a}$ & $649 a$ & 510 & $10.9 \mathrm{a}$ & $69.8 \mathrm{a}$ \\
\hline P7443R & 483 a & 322 & 531 & 22.6 & $71.7 \mathrm{bc}$ & $653 a b$ & 513 & $12.2 \mathrm{ab}$ & $65.0 \mathrm{ab}$ \\
\hline P7632HR & $407 \mathrm{~b}$ & 331 & 495 & 21.4 & $69.9 c$ & $681 \mathrm{ab}$ & 530 & $14.3 \mathrm{bc}$ & $63.8 \mathrm{ab}$ \\
\hline 39V05 & $399 \mathrm{~b}$ & 323 & 490 & 23.4 & $73.4 \mathrm{ab}$ & $674 \mathrm{ab}$ & 526 & $13.8 \mathrm{~b}$ & $61.4 \mathrm{~b}$ \\
\hline P8673AM & $302 c$ & 289 & 489 & 22.6 & $75.2 \mathrm{a}$ & $684 \mathrm{~b}$ & 524 & $16.7 \mathrm{c}$ & $50.3 \mathrm{c}$ \\
\hline \multicolumn{10}{|l|}{ Year $(\mathrm{Y})$} \\
\hline 2013 & $454 \mathrm{~b}$ & 314 & 532 & 23.1 & 72.0 & 675 & 505 & $15.9 \mathrm{~b}$ & - \\
\hline 2014 & $380 \mathrm{a}$ & NA & NA & NA & NA & NA & NA & $7.0 \mathrm{a}$ & 61.8 \\
\hline 2015 & 393 a & 322 & 481 & 21.2 & 74.4 & 662 & 536 & $17.8 \mathrm{c}$ & 62.3 \\
\hline SEM & 16.0 & 16.2 & 18.1 & 0.10 & 1.05 & 12.4 & 15.4 & 1.03 & 2.13 \\
\hline$P$-Value $\mathrm{H} \ddagger$ & $<0.001$ & 0.11 & 0.05 & 0.091 & $<0.001$ & 0.02 & 0.60 & $<0.001$ & $<0.001$ \\
\hline$P$-Value $Y \ddagger$ & $<0.001$ & 0.43 & $<0.001$ & 0.005 & 0.001 & 0.10 & 0.002 & $<0.001$ & 0.71 \\
\hline$P$-Value $\mathrm{Y} \times \mathrm{H}$ & $<0.001$ & 0.77 & 0.60 & 0.15 & 0.10 & 0.48 & 0.99 & $<0.001$ & 0.50 \\
\hline
\end{tabular}

† ADL, acid detergent lignin; $\mathrm{CP}$, crude protein; DM, dry matter; DMD, 48 hours dry matter digestibility; NA, samples were not available for analysis due to drying problems; NDF, neutral detergent fiber, all concentration of DM; NDFD, 48 hours neutral detergent fiber digestibility as concentration of NDF. $\ddagger$ Within columns, means followed by the same letter ( $a$, b, c, d) are not significantly different among hybrids or years $(p<0.05)$. 
Averaged over years and hybrids at Lethbridge, silage DM content $\left(396 \mathrm{~g} \mathrm{~kg}^{-1}\right)$, DM yield $\left(13.9 \mathrm{Mg} \mathrm{ha}^{-1}\right)$, and starch concentration $\left(320 \mathrm{~g} \mathrm{~kg}^{-1} \mathrm{DM}\right)$ reflected the greater CHU accumulation and irrigation available in this area (Table 6) compared to Lacombe. Average corn silage DM yield in 2014 at Lethbridge was lower (41\% of the other years; $p<0.05$ ) than in 2013 and 2015. In 2014, accumulated $\mathrm{CHU}_{\text {silk-harv }}$ (grain filling period) was $58 \%$ of the average of the other two years (Table 4). Although four of the six hybrids grown at Lethbridge had CHU above the climatic normal (2135), DM concentration of all hybrids was $\geq 302 \mathrm{~g} \mathrm{~kg}^{-1}$ and cob percentage exceeded $50 \% \mathrm{DM}$. When averaged over the study, hybrids had a DM content of $399 \mathrm{~g} \mathrm{~kg}^{-1}$ and cob percentage of $62 \%$. Yield of the earliest hybrid P39F44 was only $73 \%(p<0.05)$ of that of the hybrids with CHU rating of $\geq 2200$ (P7632HR, 39V05, P8673AM). Starch concentrations were relatively high for all hybrids, with no differences $(p>0.11)$ among hybrids and only relatively minor differences concentrations of $\mathrm{CP}, \mathrm{NDF}$, and DMD among hybrids $(p \leq 0.05)$.

Averaged over years and hybrids at Vauxhall DM concentration was $345 \mathrm{~g} \mathrm{~kg}^{-1}$, yield $13.4 \mathrm{Mg}$ $\mathrm{ha}^{-1}$ and starch concentration, $265 \mathrm{~g} \mathrm{~kg}^{-1} \mathrm{DM}$ (Table 7). However, these variables were all affected by year $(p<0.05)$. In 2014, average DM content and yield were lower $(p<0.05)$ than in 2013 and 2015. As was the case for Lethbridge the $\mathrm{CHU}_{\text {silk-harv }}$ at Vauxhall was lower in 2014 than the other two years (Table 4). Two corn hybrids grown at Vauxhall had CHU ratings $\leq 2250$, while the others were $\geq 2400$ CHU (Table 2). Differences $(p<0.05)$ among hybrids occurred for silage DM concentration. The two earliest hybrids (P7632HR, 39V05) achieved greater DM content than the two latest hybrids (P8673AM and P8622AM; Table 7). Starch concentration was also affected by hybrid $(p=0.028)$; but surprisingly the difference was between the two hybrids with greatest $\mathrm{CHU}$ ratings. There were no differences $(p>0.05)$ among hybrids in yield or NDF concentration, but small differences $(p<0.05)$ among hybrids were observed for ADL, DMD, NDFD $(p=0.058)$, and cob percentage $(p=0.066)$.

Averaged over years and hybrids whole plant DM, DM yield, and starch concentration were $451 \mathrm{~g} \mathrm{~kg}^{-1}, 19.2 \mathrm{Mg} \mathrm{ha}^{-1}$, and $342 \mathrm{~g} \mathrm{~kg}^{-1}$ respectively in Elm Creek, MB (Table 8). The generally high DM concentration was due to the CHU rating of the hybrids grown (Table 2), the relatively late harvest date, and the $\mathrm{CHU}$ accumulated. Although five of the six hybrids were rated less than the climatic normal $\mathrm{CHU}$ for the growing season, actual $\mathrm{CHU}$ accumulated was in line with hybrid $\mathrm{CHU}$ ratings (Table 4). Silage DM yield was greater $(p<0.05)$ in 2015 than the other years, corresponding to greater $\mathrm{CHU}_{\text {seed-harv }}$ and $\mathrm{CHU}_{\text {silk-harv }}$ than in the other years (Table 8). Surprisingly, the greater DM concentration in 2015 did not result in the greatest starch content or cob percentage; starch content was similar in 2014 and 2015 and cob percentage was actually greatest in 2013 when DM content was the lowest. On average all hybrids exceeded $400 \mathrm{~g} \mathrm{~kg}^{-1}$ silage DM and $300 \mathrm{~g} \mathrm{~kg}^{-1} \mathrm{DM}$ starch concentration at harvest, with no differences among hybrids $(p \geq 0.13)$. There were, however, differences among hybrids $(p<0.05)$ for NDF, ADL, and CP $(p=0.052)$ concentrations. The DMD and NDFD did not differ among hybrids $(p \geq 0.11)$. 
Table 7. Concentration of DM, starch, NDF, ADL, CP, DMD, NDFD, DM yield, and cob percentage for whole-plant corn grown at Vauxhall (AB, Canada) over three years.

\begin{tabular}{|c|c|c|c|c|c|c|c|c|c|}
\hline & \multicolumn{7}{|c|}{ Nutrient +} & \multirow{2}{*}{ DM Yield } & \multirow{2}{*}{ Cob } \\
\hline & DM & Starch & NDF & ADL & $\mathrm{CP}$ & DMD & NDFD & & \\
\hline & & & & $\mathrm{g} \mathrm{kg}^{-1}$ & & & & $\mathrm{Mg} \mathrm{ha}^{-1}$ & $\% \mathrm{DM}$ \\
\hline \multicolumn{10}{|l|}{ Hybrid (H) } \\
\hline P7632HR & $379 \mathrm{~d}$ & $259 \mathrm{ab}$ & 580 & $24.6 \mathrm{ab}$ & $72.8 \mathrm{a}$ & $652 \mathrm{ab}$ & 535 & 12.9 & 52.9 \\
\hline 39V05 & $369 \mathrm{~cd}$ & $253 \mathrm{ab}$ & 580 & $25.7 \mathrm{~b}$ & $76.7 \mathrm{ab}$ & $647 \mathrm{ab}$ & 533 & 13.4 & 57.5 \\
\hline P8193AM & $353 c$ & $264 \mathrm{ab}$ & 576 & $24.1 \mathrm{ab}$ & $73.7 \mathrm{a}$ & $631 \mathrm{a}$ & 507 & 13.2 & 49.2 \\
\hline P8673AM & $293 \mathrm{a}$ & $234 \mathrm{a}$ & 564 & $22.4 \mathrm{a}$ & $76.8 \mathrm{ab}$ & $672 \mathrm{~b}$ & 544 & 13.7 & 45.2 \\
\hline P8622AM & $327 \mathrm{~b}$ & $280 \mathrm{~b}$ & 560 & $23.9 \mathrm{ab}$ & $79.7 \mathrm{~b}$ & $650 \mathrm{ab}$ & 514 & 13.2 & 53.4 \\
\hline \multicolumn{10}{|l|}{ Year (Y) } \\
\hline 2013 & $386 \mathrm{c}$ & 320 & 538 & 20.2 & 75.6 & 705 & 562 & $12.9 b$ & - \\
\hline 2014 & $302 \mathrm{a}$ & NA & NA & NA & NA & NA & NA & $11.4 \mathrm{a}$ & 52.6 \\
\hline 2015 & $344 \mathrm{~b}$ & 197 & 607 & 28.1 & 76.2 & 596 & 491 & $15.5 c$ & 50.7 \\
\hline SEM & 12.0 & 13.2 & 17.4 & 0.85 & 2.09 & 10.5 & 15.6 & 1.08 & 6.93 \\
\hline$P$-Value $\mathrm{H} \ddagger$ & $<0.001$ & 0.028 & 0.66 & 0.011 & $<0.001$ & 0.002 & 0.058 & 0.90 & 0.066 \\
\hline$P$-Value $Y \ddagger$ & $<0.001$ & $<0.001$ & $<0.001$ & $<0.001$ & 0.50 & $<0.001$ & $<0.001$ & $<0.001$ & 0.47 \\
\hline$P$-Value $\mathrm{Y} \times \mathrm{H}$ & 0.17 & 0.14 & 0.52 & 0.20 & 0.35 & 0.092 & 0.14 & 0.42 & 0.43 \\
\hline
\end{tabular}

† ADL, acid detergent lignin; $\mathrm{CP}$, crude protein; DM, dry matter; DMD, 48 hours dry matter digestibility; NA, samples were not available for analysis due to drying problems; NDF, neutral detergent fiber, all concentration of DM; NDFD, 48 hours neutral detergent fiber digestibility as concentration of NDF. $\ddagger$ Within columns, means followed by the same letter (a, b, $c$, d) are not significantly different among hybrids or years $(p<0.05)$. 
Table 8. Concentration of DM, starch, NDF, ADL, CP, DMD, NDFD, DM yield, and cob percentage for whole-plant corn grown at Elm Creek (Manitoba) over three years.

\begin{tabular}{|c|c|c|c|c|c|c|c|c|c|}
\hline & \multicolumn{7}{|c|}{ Nutrient +} & \multirow{2}{*}{ DM Yield } & \multirow{2}{*}{ Cob } \\
\hline & DM & Starch & NDF & ADL & $\mathrm{CP}$ & DMD & NDFD & & \\
\hline & & & & $\mathrm{kg}^{-1}$ & & & & $\mathrm{Mg} \mathrm{ha}^{-1}$ & $\% \mathrm{DM}$ \\
\hline \multicolumn{10}{|l|}{ Hybrid (H) } \\
\hline 39D95 & 441 & 355 & $483 \mathrm{ab}$ & $20.7 b$ & 65.9 & 678 & 482 & $17.7 \mathrm{a}$ & $54.0 \mathrm{bc}$ \\
\hline P7632HR & 491 & 354 & $480 \mathrm{a}$ & $21.3 \mathrm{~b}$ & 61.6 & 689 & 499 & $19.7 \mathrm{ab}$ & $58.0 \mathrm{c}$ \\
\hline 39V05 & 449 & 335 & $515 c$ & $23.9 \mathrm{a}$ & 62.6 & 672 & 509 & $18.8 \mathrm{a}$ & $53.8 \mathrm{bc}$ \\
\hline P8673AM & 427 & 324 & $494 \mathrm{abc}$ & $21.6 \mathrm{~b}$ & 64.3 & 672 & 497 & $18.8 \mathrm{a}$ & $46.9 \mathrm{a}$ \\
\hline P8906AM & 463 & 335 & 514 bc & $22.0 \mathrm{~b}$ & 64.5 & 666 & 498 & $21.0 \mathrm{~b}$ & $49.8 \mathrm{ab}$ \\
\hline \multicolumn{10}{|l|}{ Year (Y) } \\
\hline 2013 & 381 a & 313 a & $554 \mathrm{c}$ & $23.3 \mathrm{~b}$ & $67.2 \mathrm{~b}$ & $698 c$ & $539 \mathrm{~b}$ & $20.6 \mathrm{~b}$ & $58.3 \mathrm{c}$ \\
\hline 2014 & $433 \mathrm{a}$ & $357 \mathrm{~b}$ & $442 \mathrm{a}$ & $18.2 \mathrm{a}$ & $61.5 \mathrm{a}$ & $677 \mathrm{~b}$ & $436 \mathrm{a}$ & $16.7 \mathrm{a}$ & $45.9 \mathrm{a}$ \\
\hline 2015 & $549 \mathrm{~b}$ & $353 \mathrm{~b}$ & $496 \mathrm{~b}$ & $24.2 \mathrm{~b}$ & $62.6 \mathrm{a}$ & $650 \mathrm{a}$ & $516 \mathrm{~b}$ & $20.3 \mathrm{~b}$ & $53.3 \mathrm{~b}$ \\
\hline SEM & 39.4 & 17.0 & 13.7 & 0.66 & 1.88 & 5.2 & 15.7 & 0.86 & 2.29 \\
\hline$P$-Value $\mathrm{H} \ddagger$ & 0.22 & 0.13 & 0.003 & $<0.001$ & 0.052 & 0.11 & 0.33 & 0.001 & $<0.001$ \\
\hline$P$-Value $Y \ddagger$ & $<0.001$ & $<0.001$ & $<0.001$ & $<0.001$ & $<0.001$ & $<0.001$ & $<0.001$ & $<0.001$ & $<0.001$ \\
\hline$P$-Value $\mathrm{Y} \times \mathrm{H}$ & 0.71 & 0.89 & 0.12 & $<0.001$ & 0.32 & 0.077 & 0.35 & 0.52 & 0.009 \\
\hline
\end{tabular}

+ ADL, acid detergent lignin; CP, crude protein; DM, dry matter; DMD, 48 hours dry matter digestibility; NDF, neutral detergent fiber, all concentration of DM; NDFD, 48 hours neutral detergent fiber digestibility as concentration of NDF. $\ddagger$ Within columns, means followed by the same letter $(\mathrm{a}, \mathrm{b}, \mathrm{c}, \mathrm{d})$ are not significantly different among hybrids or years $(p<0.05)$. 


\subsection{Principal Component Analysis}

Graphical representation of yield and nutrient constituents from principal component analysis (Figure 1) identified two distinct groups, which were negatively correlated, but with parameters positively correlated within groups. The $\mathrm{CP}, \mathrm{NDF}, \mathrm{ADF}$, and ADL concentrations were in one group, and DM yield, whole plant DM, starch concentration, and OM concentration and cob percentage in another. Despite being positively correlated, DMD and NDFD did not have the same relationships with other nutrients: DMD was positively correlated with starch concentration only and negatively correlated with NDF, ADF, CP, and ADL concentrations. Conversely, NDFD was negatively correlated with whole plant DM, starch, and ADL, and positively correlated with $\mathrm{CP}$ and NDF concentrations. Correlations among parameters are further detailed in Tables 9 and 10.

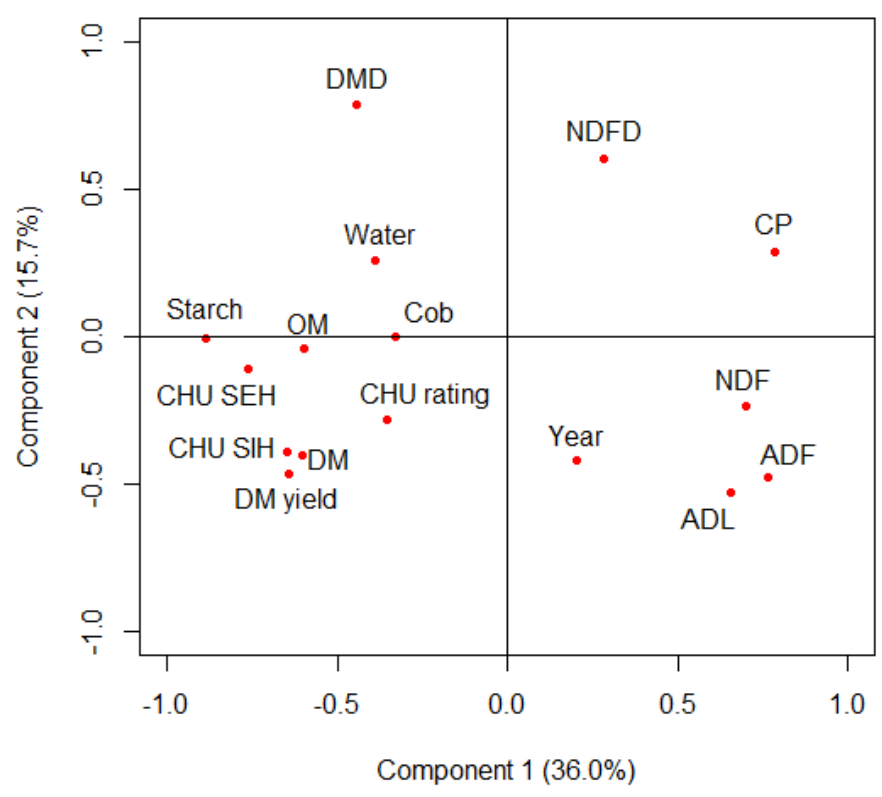

Figure 1. Component pattern plot obtained by principal component analysis describing the relationship among corn silage quality parameters and yield as well as agronomic practices (ADL, acid detergent lignin (\% DM); ADF, acid detergent fiber (\% DM); CHU rating, corn heat unit rating; CHU SHE, corn heat unit from seeding to harvesting; $\mathrm{CHU} \mathrm{SIH,} \mathrm{corn} \mathrm{heat} \mathrm{unit} \mathrm{from} \mathrm{silking} \mathrm{to} \mathrm{harvesting;} \mathrm{Cob,}$ cob percentage (\% DM); CP, crude protein (\% DM); DM, dry matter (\%); DMD, 48 hours dry matter digestibility (\% DM); DM yield ( $\left.\mathrm{T} \mathrm{ha}^{-1}\right)$; $\mathrm{OM}$, organic matter (\% $\left.\mathrm{DM}\right)$; NDF, neutral detergent fiber (\% DM); NDFD, 48 hours neutral detergent fiber digestibility (\% NDF); Starch (\% DM); Water, total water supply $(\mathrm{mm}))$.

\subsection{Correlations and Regressions}

Across locations, there was a significant correlation $(p<0.01)$ between yield and CHU rating $(r=0.42)$ indicating that later maturing hybrids within maturity zones increased yield (Table 9). Even more important for yield was $\mathrm{CHU}_{\text {seed-harv }}(r=0.55)$ and $\mathrm{CHU}_{\text {silk-harv }}$ (silking to harvest, $r=0.69$ ). Starch concentration was also highly influenced $(p<0.01)$ by CHU; CHU rating $(r=0.30), \mathrm{CHU}_{\text {seed-harv }}$ $(r=0.62)$, and $\mathrm{CHU}_{\text {silk-harv }}(r=0.61)$. Cob percentage, $\mathrm{CP}$ and NDF contents, and NDFD were inversely related to $\mathrm{CHU}(p<0.05)$, regardless of how $\mathrm{CHU}$ was expressed, whereas DMD was positively related to $\mathrm{CHU}$, but only $\mathrm{CHU}_{\text {seed-harv }}(p<0.01)$. 
Table 9. Correlation coefficients between hybrid corn heat unit rating (CHU rating), corn heat units between seeding and harvesting $\left(\mathrm{CHU}_{\text {seed-harv }}\right)$ and between silking and harvesting $\left(\mathrm{CHU}_{\text {silk-harv }}\right)$, and nutrients $\left(\mathrm{g} \mathrm{kg}^{-1}\right)$, yield $\left(\mathrm{Mg} \mathrm{ha}^{-1}\right)$, and cob percentage $(\% \mathrm{DM})$ of whole-plant corn grown for silage over all locations.

\begin{tabular}{cccc}
\hline Parameter $\mathbf{t}$ & CHU Rating & CHU $_{\text {seed-harv }}$ & CHU $_{\text {silk-harv }}$ \\
\hline DM & 0.03 & $0.49^{* *}$ & $0.52^{* *}$ \\
Starch & $0.30^{* *}$ & $0.62^{* *}$ & $0.61^{* *}$ \\
NDF & $-0.13^{*}$ & $-0.20^{* *}$ & $-0.27^{* *}$ \\
ADL & 0.03 & $-0.21^{* *}$ & $-0.05^{*}$ \\
CP & $-0.36^{* *}$ & $-0.55^{* *}$ & $-0.58^{* *}$ \\
DMD & 0.00 & $0.24^{* *}$ & -0.01 \\
NDFD & $-0.22^{* *}$ & $-0.18^{* *}$ & $-0.26^{* *}$ \\
DM yield & $0.42^{* *}$ & $0.55^{* *}$ & $0.69^{* *}$ \\
Cob percentage & $-0.38^{* *}$ & $-0.31^{* *}$ & $-0.26^{* *}$ \\
\hline
\end{tabular}

Probability of significance $*<0.05 ;{ }^{* *} p<0.01$. $+\mathrm{DM}$, dry matter; $\mathrm{CP}$, crude protein; DM, dry matter; DMD, 48 hours dry matter digestibility; NDF, neutral detergent fiber, all concentration of DM; ADL, acid detergent lignin; NDFD, 48 hours neutral detergent fiber digestibility as concentration of NDF.

Overall, starch content was highly correlated with DM content $(r=0.64, p<0.01)$, but this relationship was less evident at the cooler location of Lacombe (Table 10). Starch content $(r=-0.71)$, DM content $(r=-0.34)$, and cob percentage $(r=-0.23)$ were negatively correlated $(p<0.01)$ with NDF content, indicating the dilution effect of cob growth and grain filling on fiber content. Overall, increased plant maturity increased its digestibility, as DMD was positively correlated with starch content, and negatively affected by NDF, ADL, and NDFD contents.

Regression equations (Table 11) based on data from all locations and years showed that DM yield could be reasonably well estimated $\left(R^{2}=0.86\right)$ from the variables measured in the study with $\mathrm{CHU}_{\text {seed-harv }}$ representing $48 \%$ of the variability and water supply, $23 \%$ of the variability, followed by whole plant DM content $(14.4 \%)$, CHU rating $(11.4 \%)$, and cob percentage $(3 \%)$. Starch content could also be reasonably well explained $\left(R^{2}=0.54\right)$, mostly from $\mathrm{CHU}_{\text {seed-harv }}(39.4 \%)$ and whole plant $\mathrm{DM}$ content $(44.4 \%)$. The NDF content $\left(R^{2}=0.25\right)$, DMD $\left(R^{2}=0.10\right)$, and $\operatorname{NDFD~}\left(R^{2}=0.16\right)$ were less well explained by the variables measured. 
Table 10. Correlation coefficients between nutrients $\left(\mathrm{g} \mathrm{kg}^{-1}\right)$, yield $\left(\mathrm{Mg} \mathrm{ha}^{-1}\right)$, and cob percentage $(\% \mathrm{DM})$ of whole-plant corn grown for silage over all locations (Overall) and each location (Lacombe, Lethbridge, Vauxhall, AB; Elm Creek, Manitoba) for corn hybrids grown over three years.

\begin{tabular}{|c|c|c|c|c|c|c|c|c|}
\hline \multicolumn{9}{|c|}{ Nutrient $t$} \\
\hline & DM & Starch & NDF & $\mathrm{ADL}$ & $\mathrm{CP}$ & DMD & NDFD & Yield \\
\hline & & & & $\mathrm{g} \mathrm{kg}^{-1}$ & & & & $\mathrm{Mg} \mathrm{ha}^{-1}$ \\
\hline \multicolumn{9}{|l|}{ Overall } \\
\hline Starch & $0.64^{* *}$ & & & & & & & \\
\hline $\mathrm{NDF}$ & $-0.34^{* *}$ & $-0.71^{* *}$ & & & & & & \\
\hline ADL & $-0.13 *$ & $-0.14 *$ & 0.06 & & & & & \\
\hline $\mathrm{CP}$ & $-0.58 * *$ & $-0.71^{* *}$ & $0.48^{* *}$ & 0.15 * & & & & \\
\hline DMD & -0.04 & $0.36^{* *}$ & $-0.46^{* *}$ & $-0.40^{* *}$ & $-0.15^{*}$ & & & \\
\hline NDFD & $-0.35^{* *}$ & $-0.26^{* *}$ & $0.22^{* *}$ & $-0.22^{* *}$ & $0.41^{* *}$ & $0.43^{* *}$ & & \\
\hline DM yield & $0.47^{* *}$ & $0.54^{* *}$ & $-0.28^{* *}$ & 0.06 & $-0.63^{* *}$ & 0.06 & $-0.33^{* *}$ & \\
\hline Cob percentage & 0.01 & 0.05 & $-0.23^{* *}$ & 0.11 & 0.08 & -0.03 & -0.12 & $-0.32 * *$ \\
\hline \multicolumn{9}{|l|}{ Lacombe } \\
\hline Starch & -0.06 & & & & & & & \\
\hline $\mathrm{NDF}$ & $0.35^{* *}$ & $-0.60 *$ & & & & & & \\
\hline ADL & $0.41^{* *}$ & $-0.49^{* *}$ & $0.29 *$ & & & & & \\
\hline $\mathrm{CP}$ & $0.66^{* *}$ & -0.17 & $0.46^{* *}$ & $0.65^{* *}$ & & & & \\
\hline DMD & $-0.30 * *$ & $0.36^{* *}$ & $-0.46^{* *}$ & $-0.63^{* *}$ & $-0.47 * *$ & & & \\
\hline NDFD & $-0.62 * *$ & $0.22+$ & $-0.44^{* *}$ & $-0.43^{* *}$ & $-0.42^{* *}$ & $0.75^{* *}$ & & \\
\hline DM yield & 0.23 & -0.17 & $0.38^{* *}$ & $-0.33^{* *}$ & -0.11 & 0.22 & -0.14 & \\
\hline Cob percentage & $0.43^{* *}$ & 0.20 & -0.16 & $0.38^{* *}$ & $0.40 * *$ & -0.14 & -0.19 & $-0.46^{* *}$ \\
\hline \multicolumn{9}{|l|}{ Lethbridge } \\
\hline Starch & $0.26+$ & & & & & & & \\
\hline NDF & $0.42 * *$ & $-0.50 * *$ & & & & & & \\
\hline ADL & -0.34 * & -0.16 & $-0.26+$ & & & & & \\
\hline $\mathrm{CP}$ & $-0.49^{* *}$ & 0.05 & -0.23 & 0.17 & & & & \\
\hline DMD & -0.21 & 0.29 * & $-0.49^{* *}$ & 0.28 & 0.05 & & & \\
\hline NDFD & -0.21 & 0.23 & $-0.39^{* *}$ & -0.07 & 0.29 * & $0.39^{* *}$ & & \\
\hline DM yield & 0.00 & 0.03 & $-0.43^{* *}$ & $0.35 *$ & 0.16 & 0.24 & 0.18 & \\
\hline Cob percentage & 0.01 & 0.10 & 0.08 & -0.34 & -0.30 & -0.13 & 0.13 & $-0.78^{* *}$ \\
\hline
\end{tabular}


Table 10. Cont.

\begin{tabular}{|c|c|c|c|c|c|c|c|c|}
\hline \multicolumn{9}{|c|}{ Nutrient $t$} \\
\hline & DM & Starch & NDF & ADL & $\mathrm{CP}$ & DMD & NDFD & Yield \\
\hline \multicolumn{9}{|l|}{ Elm Creek } \\
\hline Starch & 0.28 * & & & & & & & \\
\hline $\mathrm{NDF}$ & -0.19 & $-0.77^{* *}$ & & & & & & \\
\hline ADL & $0.40^{* *}$ & 0.13 & -0.02 & & & & & \\
\hline $\mathrm{CP}$ & -0.19 & $-0.55^{* *}$ & $0.47^{* *}$ & -0.08 & & & & \\
\hline DMD & $-0.44^{* *}$ & 0.10 & -0.05 & $-0.32 * *$ & 0.04 & & & \\
\hline NDFD & 0.02 & -0.26 * & $0.64^{* *}$ & $0.20+$ & $0.33^{* *}$ & 0.25 * & & \\
\hline DM yield & 0.18 & -0.16 & $0.45^{* *}$ & $0.38^{* *}$ & 0.27 * & -0.12 & $0.51^{* *}$ & \\
\hline Cob percentage & -0.25 * & $0.35^{* *}$ & $-0.46^{* *}$ & -0.09 & -0.37 & -0.01 & $-0.36^{* *}$ & $-0.40 * *$ \\
\hline \multicolumn{9}{|l|}{ Vauxhall } \\
\hline Starch & $0.64^{* *}$ & & & & & & & \\
\hline NDF & $-0.34^{* *}$ & $-0.71 * *$ & & & & & & \\
\hline ADL & $-0.30 *$ & $-0.70 * *$ & $0.49^{* *}$ & & & & & \\
\hline $\mathrm{CP}$ & $-0.58^{* *}$ & $-0.71^{* *}$ & $0.48^{* *}$ & 0.10 & & & & \\
\hline DMD & -0.04 & $0.36^{* *}$ & $-0.46^{* *}$ & $-0.79 * *$ & -0.15 * & & & \\
\hline NDFD & $-0.35^{* *}$ & $-0.26^{* *}$ & $0.22^{* *}$ & $-0.74 * *$ & $0.41^{* *}$ & $0.43^{* *}$ & & \\
\hline DM yield & $0.31^{* *}$ & -0.34 * & 0.14 & 0.51 ** & -0.19 & $-0.46^{* *}$ & $-0.52 * *$ & \\
\hline Cob percentage & $0.47^{* *}$ & 0.17 & -0.31 & 0.33 & 0.14 & -0.01 & -0.13 & $0.44^{* *}$ \\
\hline
\end{tabular}

Probability of significance ${ }^{*} p<0.05$; ** $p<0.01$. + DM, dry matter; $\mathrm{CP}$, crude protein; DM, dry matter; DMD, 48 hours dry matter digestibility; NDF, neutral detergent fiber, all concentration of DM; ADL, acid detergent lignin; NDFD, 48 hours neutral detergent fiber digestibility as concentration of NDF. 
Table 11. Prediction equations of nutrients $\left(\mathrm{g} \mathrm{kg}^{-1}\right)$ and yield $\left(\mathrm{Mg} \mathrm{ha}^{-1}\right)$ of corn grown for silage based on indicators directly measurable in the field.

\begin{tabular}{|c|c|c|c|c|c|c|c|c|}
\hline Parameter + & Intercept & $\mathrm{CHU}_{\text {seed-harv }}$ & Total Water Supply & Whole Plant DM & CHU Rating & Cob & RMSE & $R^{2}$ \\
\hline & & & $\mathrm{mm}$ & $\mathrm{g} \mathrm{kg}^{-1}$ & & $\% \mathrm{DM}$ & & \\
\hline DM yield & $-37.7^{* *}$ & $2.6 \times 10^{-2} * *$ & $-5.0 \times 10^{-2} * *$ & $1.8 \times 10^{-2}$ & $3.6 \times 10^{-3 * *}$ & $3.3 \times 10^{-2}$ & 2.120 & 0.86 \\
\hline SE & 2.05 & $1.21 \times 10^{-3}$ & $2.40 \times 10^{-3}$ & $1.78 \times 10^{-2}$ & $8.86 \times 10^{-4}$ & $1.83 \times 10^{-2}$ & & \\
\hline Contribution & - & $48.1 \%$ & $23.0 \%$ & $14.4 \%$ & $11.4 \%$ & $3.1 \%$ & & \\
\hline Starch content & $-240.1^{* *}$ & $1.8 \times 10^{-1 * *}$ & $-1.3 \times 10^{-1} *$ & $3.2 * *$ & $2.0 \times 10^{-2}$ & - & 55.32 & 0.54 \\
\hline $\mathrm{SE}$ & 48.78 & $3.33 \times 10^{-2}$ & $6.58 \times 10^{-2}$ & 0.47 & $2.09 \times 10^{-2}$ & - & & \\
\hline Contribution & - & $39.4 \%$ & $9.9 \%$ & $44.4 \%$ & $6.3 \%$ & - & & \\
\hline NDF content & $739.8^{* *}$ & $4.5 \times 10^{-2}$ & $-9.6 \times 10^{-1 * *}$ & $-3.1^{* *}$ & $2.7 \times 10^{-2}$ & $3.4 \times 10^{-1}$ & 55.48 & 0.25 \\
\hline SE & 61.49 & $3.77 \times 10^{-2}$ & $1.94 \times 10^{-1}$ & 0.54 & $2.71 \times 10^{-2}$ & $6.15 \times 10^{-1}$ & - & - \\
\hline Contribution & - & $13.0 \%$ & $32.5 \%$ & $47.4 \%$ & $2.4 \%$ & $4.6 \%$ & & \\
\hline DMD & $631.4^{* *}$ & $-2.1 \times 10^{-3}$ & $1.2 \times 10^{-1 * *}$ & - & - & - & 36.44 & 0.10 \\
\hline SE & 25.65 & $1.54 \times 10^{-2}$ & $3.79 \times 10^{-2}$ & - & - & - & & \\
\hline Contribution & - & $29.0 \%$ & $71.0 \%$ & - & - & - & & \\
\hline NDFD & $652.6^{* *}$ & $4.5 \times 10^{-2}$ & $-7.0 \times 10^{-2}$ & $-2.0^{* *}$ & $-5.4 \times 10^{-2 * *}$ & - & 46.09 & 0.16 \\
\hline SE & 39.90 & $2.71 \times 10^{-2}$ & $5.44 \times 10^{-2}$ & 0.39 & $1.73 \times 10^{-2}$ & - & & \\
\hline Contribution & - & $10.3 \%$ & $2.9 \%$ & $65.1 \%$ & $21.7 \%$ & - & & \\
\hline
\end{tabular}

Probability of significance ${ }^{*} p<0.05 ;{ }^{* *} p<0.01$. + DM, dry matter; DMD, 48 hours dry matter digestibility; NDF, neutral detergent fiber, all concentration of DM; NDFD, 48 hours neutral detergent fiber digestibility as concentration of NDF; SE, standard error. 


\section{Discussion}

\subsection{Corn Growing Environment and Influence on Maturity}

The range in hybrid CHU ratings in the study for the four locations varied widely from 2000 to 2600 to attain the desired DM content for ensiling (320 to $380 \mathrm{~g} \mathrm{~kg}^{-1}$ silage DM). The hybrids were selected to provide variation in maturity within and across locations, and to provide some maturity overlap among hybrids. Shorter-season hybrids than optimum were used at Elm Creek along with slightly later planting dates to provide maturity overlap with cooler locations. Given the actual CHU accumulation during the study, an even earlier hybrid with $1900 \mathrm{CHU}$ rating could have been used at Lacombe, the location with the least CHU climatic normal, but unfortunately such hybrids are not yet available. Furthermore, late-maturing hybrids could have been used at Elm Creek, because the hybrids selected exceeded the desired DM content when harvested before the predicted frost. Choice of hybrid at a particular location to obtain the desirable maturity for ensilaging is important within the short-season region of the Canadian prairies. Harvesting the crop at optimum DM content optimizes silage quality. Ensiling material that is wet $(<28 \% \mathrm{DM})$ will result in seepage from the silo and reduce DM intake of cattle, while material that is too dry ( $>40 \% \mathrm{DM})$ is difficult to pack and is poorly fermented in the silo [22,23]. About $97 \%$ of DM yield accrues by $300 \mathrm{~g} \mathrm{~kg}^{-1}$ silage DM [24]; however, attaining the ideal DM concentration for ensiling proved difficult for some locations in this study (i.e., too low in Lacombe, too high in Elm Creek).

There appeared to be a difference among locations in the silage maturity response to accumulated CHU. Daynard [6] indicated that the relationship between the CHU rating (maturity) and silage DM concentration as well as occurrence of maximum DM yield could differ between warmer and cooler corn heat unit zones. Daynard [6] estimated that, in general, $250 \mathrm{~g} \mathrm{~kg}^{-1} \mathrm{DM}$ occurs approximately $500 \mathrm{CHU}$ prior to grain maturity ( $350 \mathrm{~g} \mathrm{~kg}^{-1}$ grain moisture). It follows that $300 \mathrm{~g} \mathrm{~kg}^{-1}$ and $350 \mathrm{~g} \mathrm{~kg}^{-1}$ silage DM would occur at 300 and $200 \mathrm{CHU}$ prior to grain maturity, respectively. This would allow use of later maturing corn hybrids when harvested for silage (200 CHU later than recommended for grain production) to take advantage of the positive maturity-DM yield relationship. However, at Lacombe, while all hybrids attained $250 \mathrm{~g} \mathrm{~kg}^{-1} \mathrm{DM}$, only one attained $300 \mathrm{~g} \mathrm{~kg}^{-1} \mathrm{DM}$ over three years, so grain physiological maturity at $350 \mathrm{~g} \mathrm{~kg}^{-1}$ moisture did not occur. At Lacombe, the earliest corn hybrid reached approximately $300 \mathrm{~g} \mathrm{~kg}^{-1} \mathrm{DM}$ at an average of $1900 \mathrm{CHU}_{\text {seed-harv. }}$ Using Daynard's estimate of silage drying rate vs. CHU from maturity, P39F44 at Lacombe would have reached $350 \mathrm{~g} \mathrm{~kg}^{-1} \mathrm{DM}$ at $2000 \mathrm{CHU}$ (the grain maturity rating), and not at $2200 \mathrm{CHU}$ (200 CHU later than recommended for grain production). Generally, at other locations when actual CHU exceeded the hybrid CHU rating, the silage DM concentration was greater than $400 \mathrm{~g} \mathrm{~kg}^{-1}$. At Lethbridge all but two hybrids had a CHU rating less than the average CHU accumulated (2366 CHU). Hybrid P8673AM had a rating of 2550 CHU with a silage DM concentration close to $300 \mathrm{~g} \mathrm{~kg}^{-1}$. Using Daynard's estimates this hybrid should have been close to $350 \mathrm{~g} \mathrm{~kg}^{-1} \mathrm{DM}$, given the actual CHU accumulation. Averaged over years the DM concentration at Vauxhall also tended to lag behind Daynard's estimate for silage DM concentration relative to $\mathrm{CHU}$ rating vs. accumulated CHU. An exception was P8193AM, a $2400 \mathrm{CHU}$ hybrid, which reached $353 \mathrm{~g} \mathrm{~kg}^{-1} \mathrm{DM}$ with an average of 2269 accumulated CHU. By contrast all hybrids at Elm Creek, whether CHU rating was less than or greater than $\mathrm{CHU}$ accumulated, had silage DM concentrations greater than $400 \mathrm{~g} \mathrm{~kg}^{-1}$ indicating all were close to grain physiological maturity [6]. Starch concentrations ( $\geq 324 \mathrm{~g} \mathrm{~kg}^{-1} \mathrm{DM}$ ) appeared to support grain physiological maturity as well. The Elm Creek location is considered to be well adapted for corn production in western Canada with an adaption zone rating of 2590. At Elm Creek the relatively late planting dates limited $\mathrm{CHU}_{\text {seed-harv }}$ to $88 \%$ of normal $(2259 \mathrm{CHU})$. Harvest date at Elm Creek occurred within four days of the expected frost date. Thus, at Elm Creek, it may have been necessary to include hybrids that were later than 2700 CHU rating to arrive at $350 \mathrm{~g} \mathrm{~kg}^{-1}$ silage DM.

Attaining the ideal silage DM concentration in short growing areas can be challenging and attention to drying rate details within location and year are required. Some producers simply allow 
corn to freeze in the cooler areas, but this can result in over-dry corn silage. It appears that choosing hybrids for silage with a very small difference between grain maturity $\mathrm{CHU}$ rating and adaptation zone CHU rating may be necessary in cooler areas. However, in southern areas, particularly southern Manitoba, choosing corn hybrids as much as $200 \mathrm{CHU}$ later than the adaptation zone rating for grain may be desirable. Similarly, Daynard [6] indicated that hybrid maturity rating for short-season hybrids may be reliable in warmer regions, but less so in cool regions.

\subsection{Maturity, Location, and Yield}

The yields in this study provide an indication of the relative production risk in growing a warm-season crop in cool short-season areas. Corn silage yield increases with DM content and plant maturity [25], but maximizing yield is challenging in short growing seasons. In the present study, yields were highly variable, ranging from 5.4 to $20.6 \mathrm{Mg} \mathrm{ha}^{-1}$, as previously observed in a study conducted in Lacombe [2].

Yields at Lacombe varied from season to season, but on average were likely not economical. The yields at Lacombe were comparable to those from a previous study with CS produced at Charlottetown, Prince Edward Island, Canada $\left(9.0 \mathrm{Mg} \mathrm{ha}^{-1}\right)$ with accumulated CHU of 2075 [26]. In the same study at Graysville, MB (similar to Elm Creek) with accumulated CHU ranging from 2300 to 2700 , DM yields ranged from 13.4 to $16.3 \mathrm{Mg} \mathrm{ha}^{-1}$. Significant year to year variability in CS yield was evident at Lacombe and Lethbridge when $\mathrm{CHU}_{\text {silk-harv }}$ were below average or when precipitation was below average at Lacombe. Yields at Elm Creek appeared more than adequate and are likely representative of CS potential at that location. Daynard and Hunter [24] observed that CS yield was close to maximum at $300 \mathrm{~g} \mathrm{~kg}^{-1} \mathrm{DM}$. In more suitable growing areas, Lewis, Cox and Cherney [25] reported a CS yield of $13.6 \mathrm{Mg} \mathrm{ha}^{-1}$ in New York State and Burken et al. [27] reported $22.8 \mathrm{Mg} \mathrm{ha}^{-1}$ for Nebraska.

The significant positive correlations between yield and CHU for the combined dataset is in agreement with previous research $[6,28]$. Those authors reported that, in eastern Canada, early maturing hybrids within location yielded less than later types and DM yield was greater in locations with more rather than less CHU accumulation. In the present study, the latest maturing hybrid significantly out-yielded the earliest in all locations, except at Vauxhall. While not tested statistically the warmest location (Elm Creek) had greater DM yields on average than the others while Lacombe, the coolest location, had the lowest DM yields. LeDrew, Daynard and Muldoon [28] concluded that in warmer locations silage DM accumulated to higher silage DM and lower grain moisture levels than in cooler locations. This can explain higher starch concentrations in silage than expected for the given silage DM concentrations in the warmer regions.

The regression equation developed to estimate DM yield across locations captured the importance of the environmental risks of variability in $\mathrm{CHU}$ accumulation and inadequate precipitation from year to year. In addition to environmental factors, crop maturity (DM content) and CHU rating together accounted for about $25 \%$ of the variability in CS yield indicating the importance of hybrid selection within and among adaptation zones.

\subsection{Yield, Chemical Composition, and Rumen Digestibility}

The corn hybrids used in the study were not ensiled, thus the chemical composition and rumen digestibility represent the potential for ensiling. Starch concentration of CS grown in the US averaged $326 \pm 69.5 \mathrm{~g} \mathrm{~kg}^{-1}$ (169,620 samples; [29]). In comparison, the mean starch concentration of the corn hybrids in the present study ranged from $163 \mathrm{~g} \mathrm{~kg}^{-1}$ in Lacombe (2014) to $357 \mathrm{~g} \mathrm{~kg}^{-1}$ in Elm Creek (2014) indicating high variability among locations due to maturity at harvest. Starch content was also affected by year in three of the four locations (except Lethbridge). The significant positive correlation between starch and DM concentration $(r=-0.71)$ for the overall database is consistent with the positive relationship between plant maturity and grain filling previously reported for corn [30]. However, there was an inconsistent relationship between starch and DM concentration within location. In some cases 
(e.g., Lacombe and Elm Creek) there was little variation in maturity stage at sampling. In the case of Elm Creek maturity advanced due to $\mathrm{CHU}$ accumulation being greater than hybrid rating while at Lacombe the reverse occurred resulting in immaturity with little starch. Across locations the range of maturity and adaptation to maturity zone adequately illustrates the relationship between starch and DM concentration and consequences of immature corn at harvest.

In warmer areas silage DM that accumulates late in the grain filling period is predominantly starch, and causes drying by dilution and offsets declining fiber digestibility [6,9]. Daynard [6] concluded that grain proportion may be low in CS harvested at less than $300 \mathrm{~g} \mathrm{~kg}^{-1} \mathrm{DM}$ in cool, short season areas. Thus, for CS production, cooler locations require hybrids with maturity suitable for grain production to approach a suitable grain or starch concentration. The regression equation, that showed $\left(R^{2}=0.63\right) 69 \%$ of variability in starch concentration was explained by silage DM concentration and $\mathrm{CHU}$ accumulation, indicates that warmer locations have a large advantage for starch accumulation as well as yield over cooler areas. Within location pushing harvest as close to kernel maturity as possible would be beneficial, within the silage DM window of 320 to $380 \mathrm{~g} \mathrm{~kg}^{-1}$. Further, over all locations the significant correlation between starch concentration and DM yield $(r=0.47)$ and DMD $(r=0.36)$ indicates that as kernels advance towards physiological maturity, the digestibility (and energy content) of the whole plant increases, a desirable outcome for CS as a feed for cattle. However, it is well recognized that in vivo starch digestibility may decrease with advancing maturity due to increased vitreousness of the starch, although this negative effect may be overcome by kernel processing at harvest [10].

In the present study, the mean NDF concentration $\left(530 \mathrm{~g} \mathrm{~kg}^{-1}\right)$ was greater than previously reported for CS (430 $\mathrm{g} \mathrm{kg}^{-1} \mathrm{DM}, 193,210$ samples, [29]; $450 \mathrm{~g} \mathrm{~kg}^{-1} \mathrm{DM}$, [31]). Fiber concentration of CS typically declines with maturity due to dilution effects of increasing starch concentration [32,33]. Therefore, the greater mean NDF concentration is consistent with the lower mean starch concentration in this study $(r=-0.71)$. Some studies have shown that increasing plant density also decreased NDF concentration of CS, but these relationships are not well understood [34-37]. Recommended plant density is greater for short season hybrids relative to the corn belt area of the US because short season corn plants are smaller. However, as plant densities increase, silking date and plant maturity may be delayed, which may have contributed to the lower starch and greater NDF concentration of the hybrids in the present study [36,38].

Corn silage quality also depends on its rumen availability, which can be assessed by DMD and NDFD. Whole plant DMD is an indication of energy content or total digestible nutrient content. Furthermore, a positive relationship exists between animal performance and NDFD, as a higher rumen digestibility of NDF favors greater intake by the animal [39]. In the present study, mean DMD ranged between 600 and $700 \mathrm{~g} \mathrm{~kg}^{-1}$ and mean NDFD between 500 and $550 \mathrm{~g} \mathrm{~kg}^{-1}$ of NDF, respectively. These mean values are consistent with the literature (from 450 to $700 \mathrm{~g} \mathrm{~kg}^{-1}$ for DMD, [9,32,33]; from 350 to $550 \mathrm{~g} \mathrm{~kg}^{-1} \mathrm{NDF}$ for NDFD, $\left.[39,40]\right)$ and confirm that it is possible to achieve CS with high digestibility in Northern areas. The large range of digestibility reported in the literature is related to hybrid, planting date, environmental growing conditions, maturity at harvest, cutting height, and so forth. Darby and Lauer [9] suggested that delaying planting date may increase NDFD, as plants are less mature at harvest. Delaying planting dates in short-season areas limits CHU accumulation, and hence limits DM yield, starch content, and DMD, and thus would not be advisable. Neylon and Kung [41] showed that increasing cutting height improves NDFD, which could be an option for short-season CS hybrids.

Oba and Allen [39] stated that NDFD is usually poorly correlated with NDF concentration. In the current study, despite anomalies in some locations, the overall negative correlations between NDFD and DM and starch concentrations, and positive correlations with DMD and NDF concentrations indicate that as the plants matured, NDF concentration declined, but DMD was negatively affected by lower NDFD [42]. This result corroborates the findings of Burken, Nuttelman, Gramkow, McGee, Sudbeck, Gardine, Hoegemeyer, Klopfenstein, and Erickson [27], who reported a decrease of in situ 
NDF disappearance with progressive maturity. As mentioned by Hunt, Kezar, and Vinande [32] and Johnson, Harrison, Hunt, Shinners, Doggett, and Sapienza [30], selection of high quality silage hybrids should focus on maintaining high grain yields and high fiber digestibility despite advanced stages of maturity.

With respect to cooler vs. warmer locations, the average NDFD concentration from Lacombe and Elm Creek was 558 vs. $497 \mathrm{~g} \mathrm{~kg}^{-1} \mathrm{NDF}$ respectively. This difference could not be tested statistically due to the difference in hybrids at each location. However, the difference is likely due to the relative maturity of corn hybrids at the two locations driven by CHU accumulation [9]. The average $\mathrm{CHU}$ rating of hybrids grown in Lacombe and Elm Creek was $2113 \mathrm{CHU}$ vs. $2325 \mathrm{CHU}$, which is not a large difference. Thus, the question may be posed, does the greater NDFD associated with relatively low grain content exhibited in cooler regions $[6,28]$ offset the benefits of higher starch concentration and higher silage DM concentration with greater maturity in terms of producing high energy forage for cattle [6]?

\subsection{Predicting Yield and Nutrient Concentrations}

One objective of this research was to identify factors affecting biomass yield and nutritive quality of CS grown in short-season areas. Overall, $\mathrm{CHU}_{\text {seed-harv }}$ positively influenced whole plant $\mathrm{DM}$ and DM yield. Indeed, to maximize yield in Northern environments, it is recommended to plant corn early in the season (late April or early May) to ensure the use of all available growing days and CHU [2].

Dry matter yield was reasonably predictable $\left(R^{2}=0.86\right)$ from the variables measured, with $\mathrm{CHU}_{\text {seed-harv }}(48 \%)$ and water supply $(23 \%)$ accounting for a large percentage of the variability. Starch concentration was also reasonably well predicted $\left(R^{2}=0.63\right)$, with factors affecting plant maturity at harvest explaining the variability; whole plant DM content $(40 \%), \mathrm{CHU}_{\text {seed-harv }}(30 \%)$, and total water supply $(16 \%)$. The relatively poor predictions of NDF content, DMD, and NDFD $\left(R^{2} \leq 0.25\right)$ indicated that they were mainly affected by factors not accounted for in the study.

Given that whole plant DM was positively correlated with starch concentration and negatively correlated with fiber concentration, $\mathrm{CHU}_{\text {seed-harv }}$ was positively correlated with starch and negatively correlated with NDF. The lowest starch concentration (16.3\% of DM) was recorded in 2014 in Lacombe, when the lowest $\mathrm{CHU}_{\text {seed-harv }}$ was also recorded (1780). Regarding in vitro degradabilities, $\mathrm{CHU}_{\text {seed-harv }}$ positively impacted DMD but negatively affected NDFD. This result is surprising given the positive relationship observed between DMD and NDFD. Indeed, a beneficial effect of high $\mathrm{CHU}_{\text {seed-harv }}$ on nutrient rumen digestibility was rather expected as high $\mathrm{CHU}_{\text {seed-harv }}$ enhances maturity of the plant, increases starch concentration, lowers NDF concentration, and increases NDFD percentage. Moreover, Johnson, Harrison, Hunt, Shinners, Doggett, and Sapienza [30] previously reported a positive relationship between CS digestibility and growing degree units (sum of mean daily temperature above a threshold temperature over a period of time). It is worthwhile to note that the negative correlation between NDFD and $\mathrm{CHU}_{\text {silk-harv }}$ was stronger than the correlation between

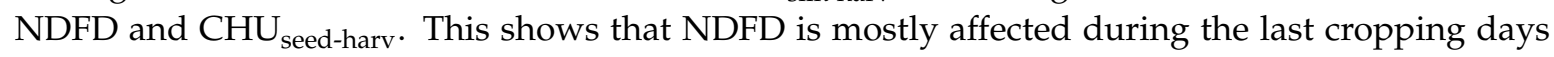
(between silking and harvesting), which is likely related to increased maturity and lignification of fiber.

The prediction equations demonstrated the impact of whole plant DM content on NDF, NDFD, and starch concentrations, $\mathrm{CHU}_{\text {seed-harv }}$ on biomass yield, and water supply on DMD content given their high contribution to the overall variability. There is no general consensus about the impact of water supply on biomass yield and nutritive value of CS. In general, CS has a high water demand (as much as $700 \mathrm{~mm}$ for growing season; [43]). In the present experiment, water supply throughout the CS cropping season was considerably lower than this level ranging between 231 and $572 \mathrm{~mm}$ among sites and years. Masoero et al. [44] reported a lack of difference in CS yield and quality grown under different water supply. Inversely and contrary to our study, Gallo et al. [45] reported a negative effect of water restriction on biomass yield and nutritive characteristics. 


\section{Conclusions}

Over 40 years the earliest maturity ratings in corn hybrids available for short-season areas, defined as regions with less than $2600 \mathrm{CHU}$, have decreased from 2300 to $2000 \mathrm{CHU}$ for grain maturity. Even so, variability in yield and attainment of consistently economical CS yields remains a challenge for cooler northern locations. This was not the case for the warmer areas of Elm Creek in southern MB and Lethbridge in southern AB. Attainment of whole plant material with a DM content of 320 to $380 \mathrm{~g} \mathrm{~kg}^{-1}$ may be difficult to achieve in some years and locations due to annual variability of $\mathrm{CHU}$ accumulation. When using the CHU hybrid rating system, which is based on grain maturity, selection of hybrids for silage will depend upon the location within the prairie region. In warmer locations, use of later maturing corn hybrids (as much as $200 \mathrm{CHU}$ later than recommended for grain production) would be ideal because the optimum DM content for ensilaging is likely to be attained before the onset of autumn frost. In contrast, in cooler areas, hybrids with CHU rating similar to the long term climatic normal CHU are recommended to maximize the DM content by the end of the growing season. It is apparent that CS produced in cooler versus warmer locations contains less starch, but the fiber is more digestible. These differences in nutritive value may necessitate different diet formulations and perhaps corn growing strategies for these distinct types of CS produced.

Author Contributions: V.S.B. and K.A.B. conceived, designed, conducted the experiment, provided guidance in the laboratory analysis of samples, and helped write the final paper; J.G. analyzed the data, prepared the tables and figures, and wrote the first draft of the manuscript.

Funding: This research was funded by the Beef Cattle Research Council of Canada (Grant number FDE.09.13) and Agriculture and Agri-Food Canada.

Acknowledgments: The authors thank Mary Lou Swift (Trouw Nutrition, AB, Canada) for NIR analyses and Lucia Holtshausen, Bev Farr, and David Young of Agriculture and Agri-Food Canada for laboratory assistance and data collection. In addition, the efforts of the field crews at each site are greatly appreciated for growing and harvesting the hybrids. Brian Beres (Agriculture and Agri-Food Canada) is thanked for his input in the organization of the study, and Pioneer Hybrid is acknowledged for providing hybrids for the study.

Conflicts of Interest: The authors declare no conflict of interest. The founding sponsors had no role in the design of the study; in the collection, analyses, or interpretation of data; in the writing of the manuscript, and in the decision to publish the results.

\section{Abbreviations}

$\begin{array}{ll}\text { ADF } & \text { acid detergent fiber } \\ \text { ADL } & \text { acid detergent lignin } \\ \text { CHU } & \text { corn heat unit } \\ \text { CHUseed-harv } & \text { CHU from seeding to harvest } \\ \text { CHUsilk-harv } & \text { CHU from silking to harvest } \\ \text { CP } & \text { crude protein } \\ \text { MRM } & \text { Minnesota relative maturity } \\ \text { CS } & \text { corn silage } \\ \text { DM } & \text { dry matter } \\ \text { DMD } & 48 \text { h dry matter digestibility } \\ \text { NDF } & \text { neutral detergent fiber } \\ \text { NDFD } & 48 \text { h neutral detergent fiber digestibility } \\ \text { OM } & \text { organic matter }\end{array}$

\section{References}

1. Owens, F. Maximizing nutritional value of corn silage: Starch versus ndf digestibility. In Proceedings of the 35th Western Nutrition Conference, WNC 2014, Edmonton, AB, Canada, 24-25 September 2014; pp. 121-143.

2. Baron, V.S.; Oba, M.; Adasen, A. Challenges for growing corn silage suitable for the dairy industry in a northern climate. Adv. Dairy Technol. 2008, 20, 181-192. 
3. Statistics Canada. Table 32-10-0416-01, Hay and Field Crops (Database). Available online: https://www150. statcan.gc.ca/t1/tbl1/en/tv.action?pid=3210041601 (accessed on 24 August 2018).

4. Baron, V.S.; Okine, E.; Campbell, D.A. Optimizing yield and quality of cereal silage. Adv. Dairy Technol. 2000, 12, 351-367.

5. Oba, M.; Allen, M.S. Evaluation of the importance of the digestibility of neutral detergent fiber from forage: Effects on dry matter intake and milk yield of dairy cows. J. Dairy Sci. 1999, 82, 589-596. [CrossRef]

6. Daynard, T.B. Practices affecting quality and preservation of whole-plant corn silage. Can. J. Plant. Sci. 1978, 58, 651-659. [CrossRef]

7. Brown, D.M.; Bootsma, A. Crop Heat Units for Corn and Other Warm-Season Crops in Ontario; Ministry of Agriculture, Food and Rural Affairs: Guelph, ON, Canada, 1993; Volume 93-119, Agdex 111/31; 4p.

8. Dwyer, L.M.; Stewart, D.W.; Carrigan, L.; Ma, B.L.; Neave, P.; Balchin, D. Guidelines for comparisons among different maize maturity rating systems. Agron. J. 1999, 91, 946-949. [CrossRef]

9. Darby, H.M.; Lauer, J.G. Harvest date and hybrid influence on corn forage yield, quality, and preservation. Agron. J. 2002, 94, 559-566. [CrossRef]

10. Bal, M.A.; Coors, J.G.; Shaver, R.D. Impact of the maturity of corn for use as silage in the diets of dairy cows on intake, digestion, and milk production. J. Dairy Sci. 1997, 80, 2497-2503. [CrossRef]

11. Michalyna, W.; Podolsky, G.; St. Jacques, E. Soils of the Rural Municipalities of Grey, Dufferin, Roland, Thompson, and Part of Stanley; Department of soil science, University of Manitoba: Winnipeg, MB, Canada, 1988.

12. Canadian Soil Information System. Soils of Canada. Available online: http://www.agr.gc.ca/atlas/ agpv?webmap-en=c225cc78d5b142d58eacefae91cc535b\&webmap-fr=ad0b6822a33e411683f99979a1167efa (accessed on 24 August 2018).

13. Soil Classification Working Group. The Canadian System of Soil Classification, 3rd ed.; NRC Research Press: Ottawa, ON, Canada, 1998.

14. Government of Canada. Environment and Natural Resources, Canadian Climate Normals. Available online: http:/ / climate.weather.gc.ca/climate_normals/results_1981_2010_e.html?searchType=stnName\& txtStationName=winnipeg\&searchMethod $=$ contains\&txtCentralLatMin $=0 \& t x+C e n t r a l L a t S e c=0 \&$ txtCentralLongMin=0\&txtCentralLongSec=0\&stnID=3698\&dispBack=1 (accessed on 24 August 2018).

15. Agriculture and Agri-Food Canada. Agroclimate Interactive Maps. Available online: http://www.agr.gc.ca/ atlas/agclimate (accessed on 24 August 2018).

16. Huggins-Rawlins, N. Agroclimatic Atlas of Alberta: Agricultural Climate Elements. Available online: http:/ / www1.agric.gov.ab.ca/\$department/deptdocs.nsf/all/sag6301 (accessed on 24 August 2018).

17. AOAC. Official methods of analysis, 18th ed.; AOAC: Arlington, VA, USA, 2005; Volume 1.

18. Van Soest, P.J.; Robertson, J.B.; Lewis, B.A. Methods for dietary fiber, neutral detergent fiber, and non starch polysaccharides in relation to animal nutrition. J. Dairy Sci. 1991, 74, 3583-3597. [CrossRef]

19. Robertson, J.B.; Van Soest, P.J. The detergent system of analysis and its application to human foods. In The Analysis of Dietary Fiber in Food; James, W.P.T., Theander, O., Eds.; Marcel Dekker: New York, NY, USA, 1981; pp. 123-158.

20. Koenig, K.M.; McGinn, S.M.; Beauchemin, K.A. Ammonia emissions and performance of backgrounding and finishing beef feedlot cattle fed barley-based diets varying in dietary crude protein concentration and rumen degradability. J. Anim. Sci. 2013, 91, 2278-2294. [CrossRef] [PubMed]

21. R Core Team. R: A Language and Environment for Statistical Computing; R Foundation for Statistical Computing: Vienna, Austria, 2014.

22. Allen, M.S.; Coors, J.G.; Roth, G.W. Corn silage. In Silage science and technology; Buxton, D.R., Muck, R.E., Harrison, J.H., Eds.; ASA, CSSA, and SSA: Madison, WI, USA, 2003; pp. 547-608.

23. Mahanna, B. Silage zone manual, 2nd ed.; Dupont Pioneer: Johnston, IA, USA, 2017.

24. Daynard, T.B.; Hunter, R.B. Relationships among whole-plant moisture, grain moisture, dry matter yield, and quality of whole-plant corn silage. Can. J. Plant. Sci. 1975, 55, 77-84. [CrossRef]

25. Lewis, A.L.; Cox, W.J.; Cherney, J.H. Hybrid, maturity, and cutting height interactions on corn forage yield and quality. Agron. J. 2004, 96, 267-274.

26. Baron, V.S.; Daynard, T.B.; Dupusi, G.; Fairey, N.A.; Major, D.J.; Muldoon, J.F.; White, R.P. Evaluation of early-maturing european and canadian corn hybrids for grain and forage production in Canada. Maydica $1987,32,33-48$. 
27. Burken, D.B.; Nuttelman, B.L.; Gramkow, J.L.; McGee, A.L.; Sudbeck, K.M.; Gardine, S.E.; Hoegemeyer, T.C.; Klopfenstein, T.J.; Erickson, G.E. Effects of agronomic factors on yield and quality of whole corn plants and the impact of feeding high concentrations of corn silage in diets containing distillers grains to finishing cattle. Transl. Anim. Sci. 2017, 1,367-381.

28. LeDrew, H.D.; Daynard, T.B.; Muldoon, J.F. Relationships among hybrid maturity, environment, dry matter yield, and moisture concentration of whole plant corn. Can. J. Plant. Sci. 1984, 64, 565-573. [CrossRef]

29. NASEM. Genetically engineered crops: Experiences and prospects; The National Academies Press: Washington, DC, USA, 2016; p. 420.

30. Johnson, L.; Harrison, J.H.; Hunt, C.; Shinners, K.; Doggett, C.G.; Sapienza, D. Nutritive value of corn silage as affected by maturity and mechanical processing: A contemporary review. J. Dairy Sci. 1999, 82, 2813-2825. [CrossRef]

31. Schwab, E.C.; Shaver, R.D.; Lauer, J.G.; Coors, J.G. Estimating silage energy value and milk yield to rank corn hybrids. Anim. Feed Sci. Technol. 2003, 109, 1-18. [CrossRef]

32. Hunt, C.W.; Kezar, W.; Vinande, R. Yield, chemical composition, and ruminal fermentability of corn whole plant, ear, and stover as affected by hybrid. J. Prod. Agric. 1992, 5, 286. [CrossRef]

33. Russell, J.R. Influence of harvest date on the nutritive value and ensiling characteristics of maize stover. Anim. Feed Sci. Technol. 1986, 14, 11-27. [CrossRef]

34. Cox, W.J.; Cherney, D.J.R. Row spacing, plant density, and nitrogen effects on corn silage. Agron. J. 2001, 93, 597-602. [CrossRef]

35. Graybill, J.S.; Cox, W.J.; Otis, D.J. Yield and quality of forage maize as influenced by hybrid, planting date, and plant density. Agron. J. 1991, 83, 559-564. [CrossRef]

36. Baron, V.S.; Najda, H.G.; Stevenson, F.C. Influence of population density, row spacing and hybrid on forage corn yield and nutritive value in a cool-season environment. Can. J. Plant. Sci. 2006, 86, 1131-1138. [CrossRef]

37. Iptas, S.; Acar, A.A. Effects of hybrid and row spacing on maize forage yield and quality. Plant. Soil Environ. 2006, 52, 515-522. [CrossRef]

38. Cusicanqui, J.A.; Lauer, J.G. Plant density and hybrid influence on corn forage yield and quality. Agron. J. 1999, 91, 911-915. [CrossRef]

39. Oba, M.; Allen, M.S. The impact of improving NDF digestibility of corn silage on dairy cow performance. In 22nd Annual Florida Ruminant Nutrition Symposium, Gainsville, FL, USA, 1-2 February, 2011; University of Florida: Gainesville, FL, USA, 2011.

40. Spanghero, M.; Zanfi, C.; Rapetti, L.; Colombini, S. Impact of ndf degradability of corn silage on the milk yield potential of dairy cows. Ital. J. Anim. Sci. 2009, 8, 211-220. [CrossRef]

41. Neylon, J.M.; Kung, L., Jr. Effects of cutting height and maturity on the nutritive value of corn silage for lactating cows. J. Dairy Sci. 2003, 86, 2163-2169. [CrossRef]

42. Mertens, D.R. Impact of NDFcontent and digestibility on dairy cow performance. Adv. Dairy Technol. 2009, 21, 191-201.

43. Marsalis, M.A.; Angadi, S.; Contreras-Govea, F.E.; Kirksey, R.E. Harvest Timing And Byproduct Addition Effects On Corn And Forage Sorghum Silage Grown Under Water Stress; College of Agricultural, Consumer and Environmental Sciences, New Mexico State University: Las Cruces, NM, USA, 2009.

44. Masoero, F.; Gallo, A.; Giuberti, G.; Fiorentini, L.; Moschini, M. Effect of water-saving irrigation regime on whole-plant yield and nutritive value of maize hybrids. J. Sci. Food Agric. 2013, 93, 3040-3045. [CrossRef] [PubMed]

45. Gallo, A.; Giuberti, G.; Masoero, F.; Palmonari, A.; Fiorentini, L.; Moschini, M. Response on yield and nutritive value of two commercial maize hybrids as a consequence of a water irrigation reduction. Ital. J. Anim. Sci. 2014, 13, 3341. [CrossRef]

(C) 2018 by the authors. Licensee MDPI, Basel, Switzerland. This article is an open access article distributed under the terms and conditions of the Creative Commons Attribution (CC BY) license (http:/ / creativecommons.org/licenses/by/4.0/). 